Article

\title{
Predicting the Impact of Climate Change on Thermal Comfort in A Building Category: The Case of Linear-type Social Housing Stock in Southern Spain
}

\author{
Rocío Escandón ${ }^{1, * \mathbb{D}}$, Rafael Suárez ${ }^{1}{ }^{\mathbb{C}}$, Juan José Sendra ${ }^{1} \mathbb{D}$, Fabrizio Ascione ${ }^{2}$, Nicola Bianco ${ }^{2}$ \\ and Gerardo Maria Mauro ${ }^{2}$ (D) \\ 1 Instituto Universitario de Arquitectura y Ciencias de la Construcción, Escuela Técnica Superior de \\ Arquitectura, Universidad de Sevilla, Av. Reina Mercedes 2, 41012 Seville, Spain; rsuarez@us.es (R.S.); \\ jsendra@us.es (J.J.S.) \\ 2 Department of Industrial Engineering, Università degli Studi di Napoli Federico II, Piazzale Tecchio 80, \\ 80125 Napoli, Italy; fabrizio.ascione@unina.it (F.A.); nibianco@unina.it (N.B.); \\ gerardomaria.mauro@unina.it (G.M.M.) \\ * Correspondence: rescandon@us.es; Tel.: +34-954559517
}

Received: 13 May 2019; Accepted: 10 June 2019; Published: 12 June 2019

\begin{abstract}
The Climate Change scenario projected by the IPCC for the year 2050 predicts noticeable increases in temperature. In severe summer climates, such as the Mediterranean area, this would have very negative effects on thermal comfort in the existing housing stock, given the current high percentage of dwellings which are obsolete in energy terms and house a population at serious risk of energy poverty. The main aim of this paper is to generate a predictive model in order to assess the impact of this future climate scenario on thermal comfort conditions in an entire building category. To do so, calibrated models representing linear-type social multi-family buildings, dating from the post-war period and located in southern Spain, will be simulated extensively using transient energy analyses performed by EnergyPlus. In addition, a sensitivity analysis will be performed to identify the most influential parameters on thermal discomfort. The main results predict a generalized deterioration in indoor thermal comfort conditions due to global warming, increasing the average percentage of discomfort hours during the summer by more than $35 \%$. This characterization of the future thermal behaviour of the residential stock in southern Spain could be a trustworthy tool for decision-making in energy retrofitting projects which are so badly needed. To do so, further work is required on some limitations of this model so that different user profiles and typologies can be represented in detail and an economic assessment can be included.
\end{abstract}

Keywords: social housing stock; thermal comfort; Mediterranean climate; building performance simulation; climate change; sensitivity analysis

\section{Introduction}

Given the contrasted climate evolution towards an increase in global temperatures, numerous studies and organizations agree on the need to warn society about the risks faced. This global warming, directly related to greenhouse gas emissions, is attributed to a large extent to the building sector, considered one of the major energy consumers worldwide. In the European Union specifically, over 25\% of final end-use energy was associated to the household category in 2015 [1].

The Intergovernmental Panel on Climate Change (IPCC) [2] periodically publishes a series of reports compiling and synthesizing the most significant studies on climate change to date. In the Special Report on Emissions Scenarios [3], the IPCC presents a set of future scenarios-A1, A2, B1 and B2-in accordance with social and economic variables and with different predictions for the evolution 
of $\mathrm{CO}_{2}$ concentration. $\mathrm{A} 2$ is the most unfavourable scenario, with the highest $\mathrm{CO}_{2}$ concentration predicted for the year 2100, and is therefore considered a priority in the research of the impact and consequences of climate change.

Different authors evaluated the influence of the global increase in temperature on the energy performance of buildings [4,5]. It is worth highlighting the research by Santamouris [6], who, based on recent studies conducted in different regions of the world, developed a model which predicts an increase of up to $35 \%$ in global cooling consumption in the housing sector for 2050, mainly due to climate change, the increase in population, and income growth. Focusing on the Mediterranean climate, Kapsomenakis et al. [7] evaluated the impact of the outdoor temperature increase over the last 40 years on the energy consumption of an office building in Greece, concluding a cooling demand increase of around $5 \mathrm{kWh} / \mathrm{m}^{2}$ per decade. Suárez et al. [8] estimated that the buildings built in southern Spain since 2006 - in accordance with the limitations set by the current Spanish energy saving regulation [9] — will double their cooling demand under the 2050 climate change scenario.

In addition to the increase in energy consumption, climate change will worsen indoor thermal conditions in the dwellings inhabited by the social groups which are economically more vulnerable, as they cannot afford to use active air conditioning systems $[10,11]$. The global increase in outdoor temperatures will lead to indoor overheating conditions which must be addressed in order to eliminate the risk of energy poverty [12].

This situation poses a series of challenges for the building sector [13,14]. On the one hand, the design of new buildings should ensure the minimum polluting emissions from construction sites, maximum energy efficiency and a near-zero energy consumption, but what will happen to existing buildings? Their environmental performance will worsen and thermal conditioning needs will increase, meaning that they are in urgent need of retrofitting in order to be able to tolerate the future climatic conditions [15].

In southern Europe, a large percentage of dwellings, between 63\% [16] and 76\% [17], predate the first regulations limiting energy demand in buildings (1976-1979). As a result, there is a relevant part of the residential stock with obsolete energy performance, and its population will suffer the most due to the negative effects of climate change if investment is not made in retrofitting [18]. Numerous studies defend the need to characterize case studies before proposing energy retrofitting measures $[19,20]$ in order to be able to calibrate simulation models and to avoid the 'performance gap' between real and predicted consumptions [21,22]. This characterization must take into account the long-term climate perspective to ensure that retrofitting projects do not become obsolete as soon as they are completed.

This environmental or energy characterization can be carried out individually or through building stock models. When evaluating a set of buildings—such as a building category or entire housing stock-there are two methods: top-down and bottom-up [23]. A high percentage of the models evaluating the energy performance of large building stocks makes use of top-down techniques, based mainly on historical and statistical data. These models have been used in order to characterize the energy consumption of residential stocks in northern [24,25] and southern Europe [26,27], attempting to identify key challenges to energy saving. Given that the results of these models are largely based on previous data, these techniques are less convenient when evaluating the building performance under climate projections.

In the last few decades, bottom-up engineering techniques have been the most commonly used when a detailed computation of the energy performance of buildings is required. These techniques are based on data collection from study samples to be extrapolated at the regional or national level using simulation models [28]. The simulation tools most frequently employed by the scientific community are EnergyPlus [29], ESP-r [30] and TRNSYS [31], which ensure highly accurate results. This is the case of the model developed by Wang et al. [32] for the evaluation of retrofitting measures, in terms of energy demand, for residential districts in Switzerland and that designed by Penna et al. [33] for different Italian cities. Based on the results of these building stock models, surrogate models can be developed, which drastically reduce computational times [34,35]. 
Nowadays, most simulations use typical weather files, which are available in the databases frequently used by the scientific community and are usually obsolete. These weather data do not match the real situation of housing stock in the coming years as a result of global warming, a phenomenon which will be further worsened in cities due to urban heat island effects, according to the available literature $[10,36]$. Therefore, this work aims to quantify the impact of future climate change scenarios on the thermal behaviour of a building category. In order to do this, a building stock model will be developed using the EnergyPlus [29] simulation tool, characterizing the environmental behaviour of an entire building category under the typical climate conditions of the city of Seville and those of its corresponding climate change scenario for 2050.

\section{Materials and Methods}

The starting point for the methodology of this work is a building stock model previously developed for the environmental characterization of the entire building category: linear multi-family social housing developed in southern Spain between the 1950s and the 1980s. The development and calibration of this model through in-situ measurements is described in depth in a previous publication [37].

This research applied the SLABE (Simulation-based Large-scale uncertainty/sensitivity Analysis of Building Energy performance) method defined by Mauro et al. [38], providing a reliable environmental evaluation model for any building belonging to the category studied. This model focuses its evaluation on the percentage of discomfort hours, since this building category is generally characterized by summer and winter natural ventilation, i.e., free-running indoor temperatures, with a very sporadic use of mechanical local cooling or heating systems. In order to be able to contrast with in-situ measurements, this initial model made use of outdoor climatic conditions referenced for the monitoring period (years 2014 and 2015).

A climate data projection for 2050 will be developed for application in the model simulation in order to assess the influence of global warming on the thermal behaviour of this building category. This comparison of the results obtained for the typical and 2050 climatic conditions is the main originality of the proposed methodology. In addition, a sensitivity analysis will be performed to ascertain the parameters with most influence on thermal discomfort.

Finally, the simulation models within the building category with the best and worst annual thermal performance will be determined to develop a detailed evaluation of their characteristic parameters and environmental behaviour. The influence of climate change in terms of energy demand will also be estimated for these case studies. Figure 1 summarizes the process followed throughout this study.

\subsection{Building Category Characterization: The SLABE Method}

The simulation tool EnergyPlus [29] was chosen to assess the level of thermal comfort in the building category as it allows a detailed assessment of the indoor temperature and works with text-based format inputs and outputs, allowing communication with mathematical tools for processing the results. A calibrated model representing a specific building belonging to the category was used as a starting point. The peripheral and surrounding buildings were also defined (geometry, material and transmittance) in this model, interacting with the case study in terms of shading, reflection and longwave emission. In addition, the roughness of the terrain typical of suburban locations was considered for the calculation of local wind speed. 
Thermal comfort assessment

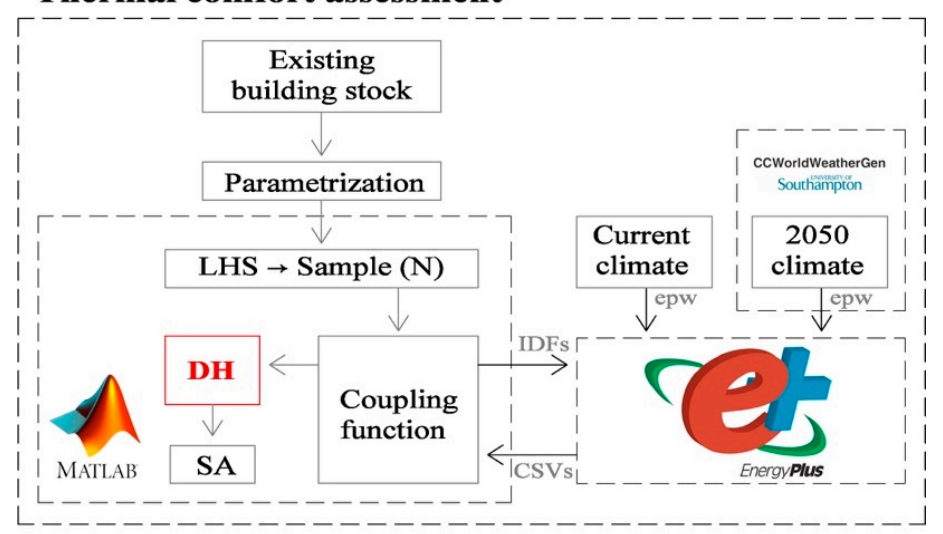

Energy demand assessment

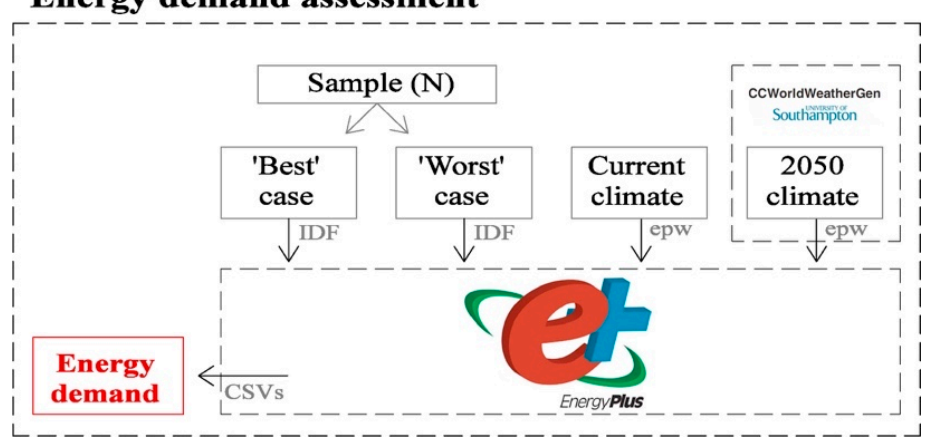

Figure 1. Methodology scheme.

Based on this initial model, the input data are replaced by parameters. For the purpose of switching from an individual case study model to a building stock one, a variability range and probability distribution (uniform or normal) should be attributed to these parameters. Latin Hypercube Sampling is then applied to these variables within a Monte Carlo framework, developing a specific number of case studies. This method ensures the uniformity and representativeness of the study sample [39]. In this case, the sample size was set as $\mathrm{N}=750$ cases, a value previously considered optimum for this building stock model in order to ensure the best performance in the case of future development of an Artificial Neural Network based on these simulation results [37]. This sample size gives rise to a ratio between $\mathrm{N}$ and the number of characteristic parameters over 25, which is much higher than the ratio of between 2 and 5 recommended in the available bibliography commonly studying a specific case study [40]. Conraud sets a minimum $\mathrm{N}$ of $5 x$ number of inputs $x$ number of outputs [41]. Given that the analysis of a building category involves higher ranges of variability in the characteristic parameters, a higher sample size was set to guarantee the significance of the results.

In this work, the building category represents a stock of buildings with the same geometric and constructive typology, similar user profiles (e.g., a limited use of HVAC, restricted economic conditions since it is social housing, etc.) and the same climate conditions. It should not include different building typologies, since this makes the ranges of variability of the characteristic parameters excessively broad and compromises the model's reliability.

With regards to the extensive research carried out here, the simulation of the $\mathrm{N}$ cases in EnergyPlus is automatically commanded by MATLAB [42] and the thermal comfort prediction is obtained for the study sample in terms of percentage of discomfort hours (DH). Discomfort hours are defined as the occupied hours with indoor temperatures outside the comfort acceptability range, according to the equations established in Section 2.2. The DH provided is a global value for the whole building, obtained from the calculation of the average $\mathrm{DH}$ value for each dwelling.

In addition, a sensitivity analysis (SA) is developed to determine which parameters have the most influence on DH. A global method was selected for the SA, evaluating the Standardized Rank 
Regression Coefficients (SRRCs) [38]. According to the available literature [43,44], this approach is the most appropriate for the type of relations between inputs and outputs in this study: non-linear but monotonic. The SRRC ranges from -1 to 1 , with a positive value representing input and output parameters changing with the same sign, and the opposite for a negative one.

\subsection{Adaptive Comfort Standards}

For the purposes of the evaluation of thermal comfort, most of the international standards are based on Fanger studies [45]. They assess thermal comfort according to two indices: the Predicted Mean Vote (PMV) and the Predicted Percentage of Dissatisfied (PPD). Standard EN ISO 7730 [46], based on this methodology, is one of the most widely used by the scientific community. However, when the case study is a naturally ventilated building, the use of adaptive standards is considered more suitable for thermal comfort assessment than standards based on the PMV index [47-49]. The main reason is that in residential buildings, users are completely free to vary the amount of clothing they have on and to open the windows to improve thermal sensation. As a result, these variables are very difficult to fix.

According to previous research [50,51], the specific case study of social housing in southern Spain requires a revision of the suitability of applying the adaptive thermal comfort standards most commonly accepted by the scientific community. These studies conclude that, while the two most extensively used adaptive thermal comfort standards-ASHRAE Standard 55 [52], ISO-EN-15251 [53] and its revision prEN 16798-1:2015 [54] - function properly for the winter climatic conditions in southern Spain, this is not the case with indoor overheating conditions in summer. In fact, with the maximum outdoor temperatures considered in both standards, $33.5^{\circ} \mathrm{C}$ and $30^{\circ} \mathrm{C}$, respectively, indoor temperatures above $31^{\circ} \mathrm{C}$ are included in the comfort range. In this specific study and based on the conclusions of the analysis carried out, thermal comfort levels are assessed as follows:

- From December to February (winter period), the adaptive thermal comfort standard defined in ISO-EN-15251 was applied (optimum comfort temperature (Tco) according to Equation (1)). This equation is only suited to naturally ventilated buildings, with low metabolic rate activities. The acceptability range defined is a temperature interval of $\pm 4{ }^{\circ} \mathrm{C}$, associated to building category III (corresponding to PPD $<15 \%$ ), which is defined only for existing buildings.

$$
\text { Tco }{ }_{\text {winter }}=0.33 \times T_{e R}+18.8
$$

where:

$T_{e R}:$ running mean dry bulb outdoor temperature for today (Equation 2)

$$
T_{e R}=(1-\alpha) \times T_{e d-1}+\alpha \times T_{e R-1}
$$

where:

$T_{e d-1}$ : daily mean dry bulb outdoor temperature for previous day;

$T_{e R-1}$ : running mean dry bulb outdoor temperature for previous day;

$\alpha$ : a constant between 0 and 1 . Use of 0.8 is recommended.

- From March to November (summer, spring and autumn periods), the alternative adaptive thermal comfort standard defined by Barbadilla-Martín et al. for the Mediterranean climate was applied (Tco calculated following equation 3) [55]. This standard is only applicable to 'Mixed Mode' buildings, i.e., naturally ventilated buildings which also have an air conditioning system in occasional use. For this standard, the acceptability range defined is a temperature interval of 
$\pm 3.5^{\circ} \mathrm{C}$, corresponding to a predicted percentage of dissatisfied (PPD) under 20\%. In Equation (3), $T_{e R}$ is the running mean dry bulb outdoor temperature for today (see also Equation (2)).

$$
\text { Tco }_{\text {summer }}=0.24 \times T_{e R}+19.3
$$

\subsection{Environmental Assessment for Climatic Conditions of the Year 2050}

In order to evaluate the influence of a climate change scenario on the environmental performance of a whole building category, climate data are modified in the initial model simulation, taking into account the climate change scenario projection for the year 2050.

The climate data projection for 2050 was carried out using CCWorldWeatherGen software, developed by the University of Southampton [56]. The operation of this tool is based on the 'morphing' method for climate change conversion of weather data defined by Belcher et al. [57]. The original climate data file from the Seville Airport meteorological station, provided by the EnergyPlus database [58], was converted into one that takes into account future conditions resulting from a climate change scenario [59]. In this specific case study, the IPCC Third Assessment Report model summary data of the Hadley Centre Coupled Model version 3 (HadCM3) for the A2 scenario was used [60]. It is the most adverse scenario, regarding the 2050 prediction of $\mathrm{CO}_{2}$ particles per million.

The simulation of the environmental behaviour of the building category follows the same methodology described in Section 2.1, but replaces the original climate data file with that developed by the CCWorldWeatherGen tool for 2050. The comparison between the results of both simulation models -current climate vs. 2050 projection-allows the influence of the temperature increase in the climate change scenario to be assessed for an entire residential building category in the Mediterranean climate.

\subsection{Environmental and Energy Assessment of the 'Best' and the 'Worst' Case Study}

Once environmental behaviour is evaluated in terms of discomfort hours for the entire building category, the cases with the best, that is, the lowest $\mathrm{DH}$, and worst thermal behaviour or highest $\mathrm{DH}$ throughout the year are determined. For these two case studies, the hourly evolution of the temperature for a dwelling located on an intermediate floor was analysed on a typical winter (January 16) and summer day (July 27), taking into consideration typical climatic conditions and those projected for the year 2050. This establishes a range of results in order to quantify the influence of global warming on the indoor temperature of this building category in southern Spain.

Finally, the annual energy demand for heating and cooling is estimated to calculate the requirements of both case studies in order to ensure indoor comfort conditions under the climate change scenario. These results are also compared with the values obtained for the typical climatic conditions.

\section{Case Study}

\subsection{Definition of the Building Category Case Study}

The methodology described above was applied to a specific building category in southern Spain, that of a group of multi-family social housing buildings dating from 1960 to 1980, following a linear geometric typology (Figure 2). This covers the stage of major urban growth in Spain, as a result of the implementation of public plans encouraging the construction of social housing answering the great need for accommodation resulting from the Civil War. Furthermore, there were no global regulations limiting energy demand during this period. This study was carried out in the city of Seville, where the linear typology was the most common during the post-war-period, accounting for over $40 \%$ of the social housing stock, that is, more than 4000 buildings in total [61].

Seville has a Mediterranean climate, with mild winters and hot dry summers. The Spanish Government [9] categorizes Seville as Zone B4. This means rather warm winters (zone B-low severity) and very hot summers (zone 4 -high severity). The main standard climate values for Seville are shown in Table 1. 

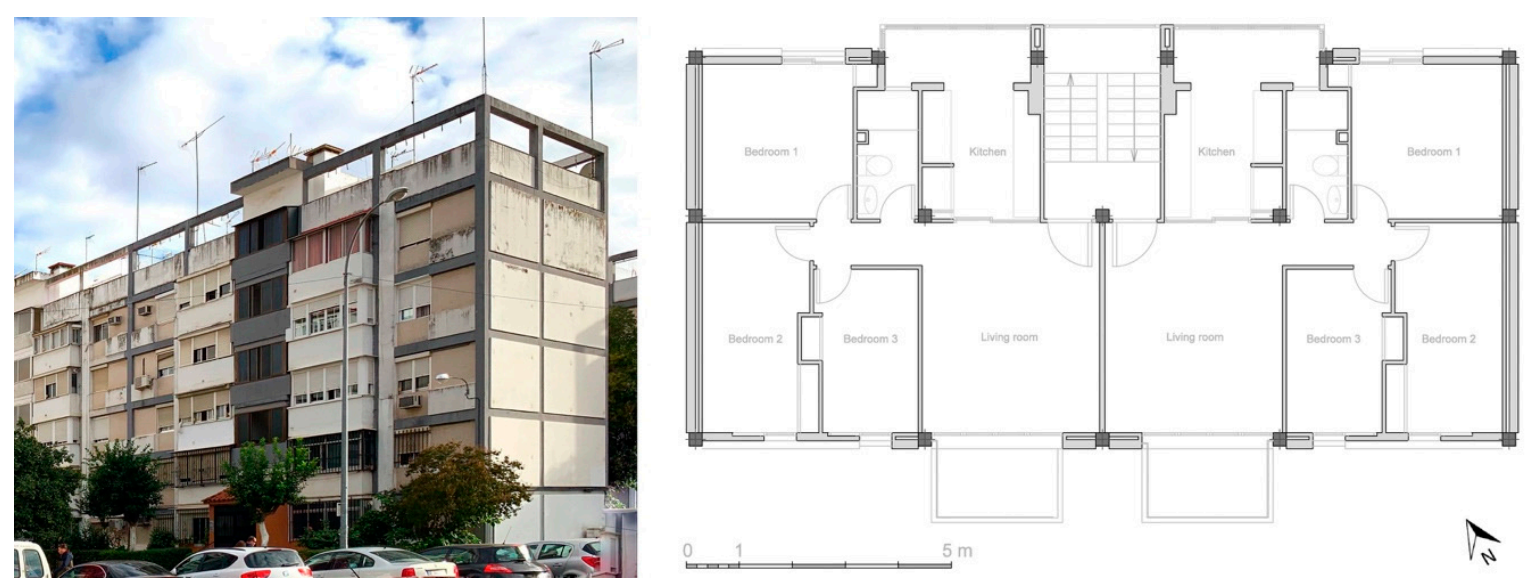

Figure 2. Exterior view and floor plan of a reference building belonging to the case study category.

Morphological and constructive data were collected from over 100000 dwellings in Seville from the post-war period [61] as part of an R\&D\&I project developed between 2013 and 2016 [62]. More than 42000 dwellings from the entire sample fall within the building category analysed in this paper. The information compiled in this project is used to establish the range of variability of the parameters which define the building category, using the extreme values of the sample to determine the upper and lower limits. When the parameter has similar probabilities of taking all the values of the range, a uniform distribution is selected, whereas a normal distribution is determined when the parameter has a higher probability of assuming the mean value of the range. Table 2 shows the ranges of variability and probability distribution for each parameter.

In southern Spain, just 5\% of multi-family dwellings prior to 1980 are equipped with central heating, while only $13 \%$ have a local heating system [16]. In contrast, $66.2 \%$ of multi-family dwellings built before 1980 incorporate cooling equipment [63], although in most cases these are local systems used intermittently to provide service to a single room. As tends to be the general case in social housing in southern Spain, most of the time the dwellings in this building category do not use any active HVAC system. Moreover, as the costs of air-conditioning technologies are continuously falling, it is highly likely that there will be a widespread increase in the use of split cooling systems in coming years. Of course, given the very real possibility that these might worsen local global warming, there is clearly a risk of falling into a dangerous vicious circle.

Table 1. Annual standard climate values, period 1981-2010 [64].

\begin{tabular}{lc}
\hline \multicolumn{2}{c}{ Seville: Climate Characteristics } \\
\hline Altitude $[\mathrm{m}]$ & 34 \\
Latitude & $37^{\circ} 25^{\prime} 0^{\prime \prime} \mathrm{N}$ \\
Longitude & $5^{\circ} 52^{\prime} 45^{\prime \prime} \mathrm{W}$ \\
Average temperature $\left[{ }^{\circ} \mathrm{C}\right]$ & 19.2 \\
Average maximum daily temperature $\left[{ }^{\circ} \mathrm{C}\right]$ & 25.4 \\
Average minimum daily temperature $\left[{ }^{\circ} \mathrm{C}\right]$ & 13.0 \\
$99 \%$ winter design temperature (annual) $\left[{ }^{\circ} \mathrm{C}\right]$ & 4.5 \\
Winter mean DTR $\left[{ }^{\circ} \mathrm{C}\right]$ & 12.9 \\
$1 \%$ summer design temperature (annual) $\left[{ }^{\circ} \mathrm{C}\right]$ & 37.6 \\
Summer mean DTR $\left[{ }^{\circ} \mathrm{C}\right]$ & 17.4 \\
Average relative humidity [\%] & 59 \\
Average daily global irradiation $\left[\mathrm{kWh} / \mathrm{m}^{2}\right]$ & 5.23 \\
Average hours of sunlight & 2917 \\
\hline
\end{tabular}

In order to estimate the energy demand required to ensure indoor comfort conditions in the dwellings belonging to the category studied, a hypothetical use pattern is defined for heating and 
cooling systems based on the comfort temperatures established by Spanish regulations [9]. This pattern is defined in Table 3.

Table 2. Characterization of the parameters of building category case study.

\begin{tabular}{|c|c|c|c|c|}
\hline \multicolumn{3}{|r|}{ Parameter } & \multirow{4}{*}{$\begin{array}{c}\begin{array}{c}\text { Building Category } \\
\text { Stock }\end{array} \\
1940-1980 \\
\text { Linear } \\
42140\end{array}$} & \multirow[t]{4}{*}{ Distribution } \\
\hline General & - & Year of construction & & \\
\hline & - & Typology & & \\
\hline & - & No. dwellings & & \\
\hline \multirow[t]{9}{*}{ Geometry } & $P_{1}$ & Orientation (Figure 3) & $0^{\circ}-180^{\circ}$ & Uniform \\
\hline & $\mathrm{P}_{2}$ & Area of each floor $\left[\mathrm{m}^{2}\right]$ & $90-300$ & Uniform \\
\hline & $\mathrm{P}_{3}$ & Form ratio ${ }^{1}$ & $1-5$ & Uniform \\
\hline & $\mathrm{P}_{4}$ & Floor height $[\mathrm{m}]$ & $2.4-3.5$ & Uniform \\
\hline & $\mathrm{P}_{5}$ & Window to wall ratio: $S$ & $10 \%-40 \%$ & Uniform \\
\hline & $\mathrm{P}_{6}$ & Window to wall ratio: $\mathrm{E}$ & $10 \%-40 \%$ & Uniform \\
\hline & $\mathrm{P}_{7}$ & Window to wall ratio: $\mathrm{N}$ & $10 \%-40 \%$ & Uniform \\
\hline & $\mathrm{P}_{8}$ & Window to wall ratio: $\mathrm{W}$ & $10 \%-40 \%$ & Uniform \\
\hline & $\mathrm{P}_{9}$ & Number of stories & $3-7$ & Uniform \\
\hline \multirow[t]{21}{*}{ Envelope } & $P_{10}$ & Roof solar absorptance (a) & $0.1-0.9$ & Normal \\
\hline & $\mathrm{P}_{11}$ & Façade solar absorptance (a) & $0.1-0.9$ & Normal \\
\hline & $\mathrm{P}_{12}$ & Floor thickness [m] & $0.15-0.30$ & Normal \\
\hline & $\mathrm{P}_{13}$ & Floor thermal conductivity $[\mathrm{W} / \mathrm{m} \mathrm{K}]$ & $0.70-1.80$ & Normal \\
\hline & & Floor $\mathrm{U}$ value $\left[\mathrm{W} / \mathrm{m}^{2} \mathrm{~K}\right]$ & $4.70-7.00$ & Normal \\
\hline & $\mathrm{P}_{14}$ & Floor density $\left[\mathrm{kg} / \mathrm{m}^{3}\right]$ & $1500-1800$ & Normal \\
\hline & $\mathrm{P}_{15}$ & Floor specific heat $[\mathrm{J} / \mathrm{kg} \mathrm{K}]$ & $500-1500$ & Normal \\
\hline & $\mathrm{P}_{16}$ & Roof thickness [m] & $0.20-0.40$ & Normal \\
\hline & $P_{17}$ & Roof thermal conductivity [W/m K] & $0.31-0.57$ & Normal \\
\hline & & Roof $\mathrm{U}$ value $\left[\mathrm{W} / \mathrm{m}^{2} \mathrm{~K}\right]$ & $1.25-2.40$ & Normal \\
\hline & $\mathrm{P}_{18}$ & Roof density $\left[\mathrm{kg} / \mathrm{m}^{3}\right]$ & $1000-1800$ & Normal \\
\hline & $\mathrm{P}_{19}$ & Roof specific heat $[\mathrm{J} / \mathrm{kg} \mathrm{K}]$ & $500-1500$ & Normal \\
\hline & $\mathrm{P}_{20}$ & Façade thickness $[\mathrm{m}]$ & $0.10-0.35$ & Normal \\
\hline & $\mathrm{P}_{21}$ & Façade thermal conductivity [W/m K] & $0.19-0.46$ & Normal \\
\hline & & Façade $U$ value $\left[\mathrm{W} / \mathrm{m}^{2} \mathrm{~K}\right]$ & $0.75-4.35$ & Normal \\
\hline & $\mathrm{P}_{22}$ & Façade density $\left[\mathrm{kg} / \mathrm{m}^{3}\right]$ & $1000-3000$ & Normal \\
\hline & $\mathrm{P}_{23}$ & Façade specific heat [J/kg K] & $500-1500$ & Normal \\
\hline & $\mathrm{P}_{24}$ & Internal partitions thickness [m] & $0.07-0.24$ & Normal \\
\hline & $\mathrm{P}_{25}$ & Type of window glass & Single; Double & Uniform \\
\hline & $\mathrm{P}_{26}$ & Type of window frame & Aluminium; Wood & Uniform \\
\hline & & Window $U$ value $\left[\mathrm{W} / \mathrm{m}^{2} \mathrm{~K}\right]$ & $2.80-5.70$ & Uniform \\
\hline \multirow[t]{3}{*}{ Operation } & $\mathrm{P}_{27}$ & People density [people/m²] & $0.01-0.15$ & Normal \\
\hline & $\mathrm{P}_{28}$ & Infiltration rate $\left[\mathrm{h}^{-1}\right][65]$ & $0.3-1.0$ & Normal \\
\hline & $\mathrm{P}_{29}$ & Night-time natural ventilation rate $\left[\mathrm{h}^{-1}\right]$ & $0 ; 2 ; 4 ; 6$ & Uniform \\
\hline
\end{tabular}

Table 3. Heating and Cooling patterns for the estimation of energy demand [9].

\begin{tabular}{ccc}
\hline Pattern & \multicolumn{2}{c}{ Schedule } \\
\hline & $0: 00-8: 00 \mathrm{~h}$ & $8: 00-0: 00 \mathrm{~h}$ \\
\hline Heating & $17^{\circ} \mathrm{C}$ & $20^{\circ} \mathrm{C}$ \\
Cooling & $27^{\circ} \mathrm{C}$ & $25^{\circ} \mathrm{C}$ \\
\hline
\end{tabular}

\subsection{Climate Change Scenario (Year 2050)}

The evolution of the main climate values throughout the year was evaluated, comparing the data from the weather file for the typical climate conditions in Seville [58] and the data projected for 
the year 2050 (see Section 2.3). As Figure 4a shows, the new climate scenario means an increase in average monthly outdoor temperatures from $1.6^{\circ} \mathrm{C}$ in December to $4.1^{\circ} \mathrm{C}$ in July. This increase in the outdoor temperatures will obviously affect the indoor temperatures and the time of use of cooling systems. While current Spanish regulations set the period of use of cooling systems between June and September [9], the projection for 2050 also results in average monthly outdoor temperatures over $20^{\circ} \mathrm{C}$ in May and October, which will most likely extend the period of use of the cooling systems in a climate change scenario.

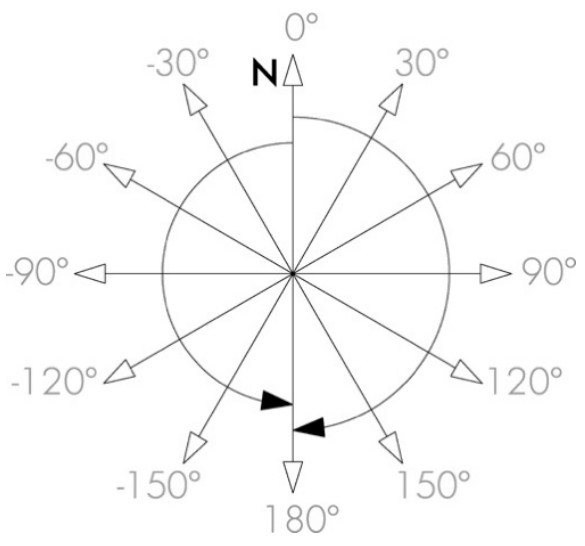

Figure 3. Orientations considered.

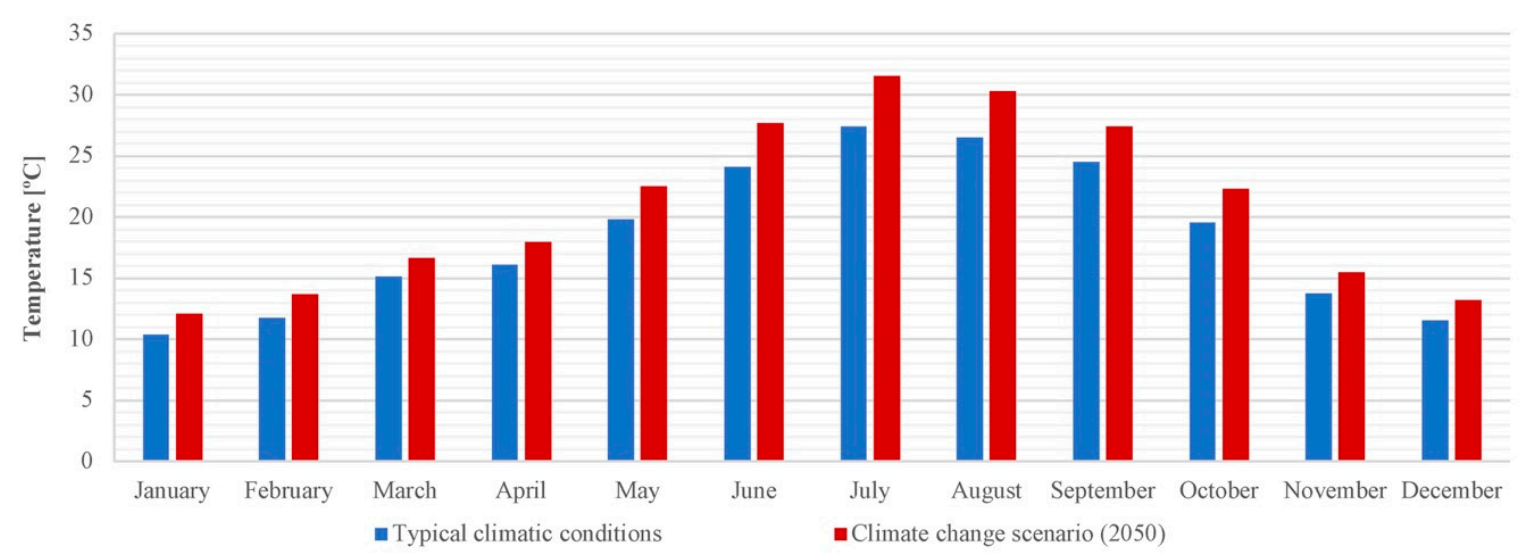

(a)

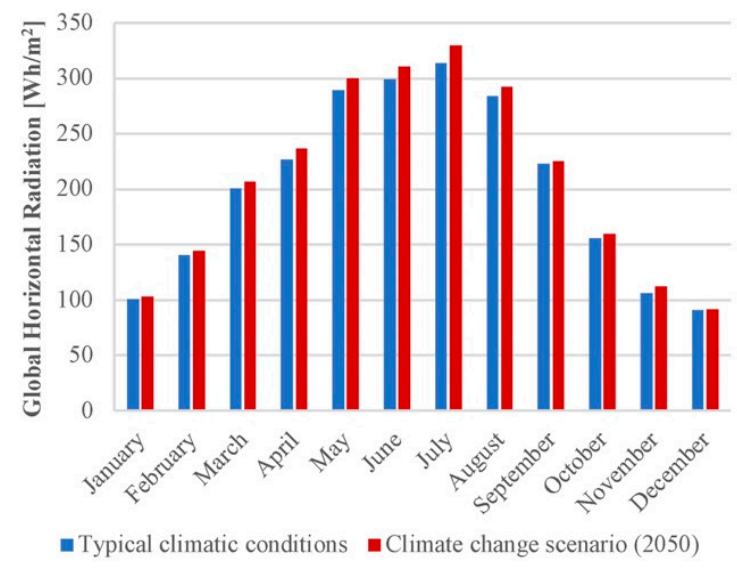

(b)

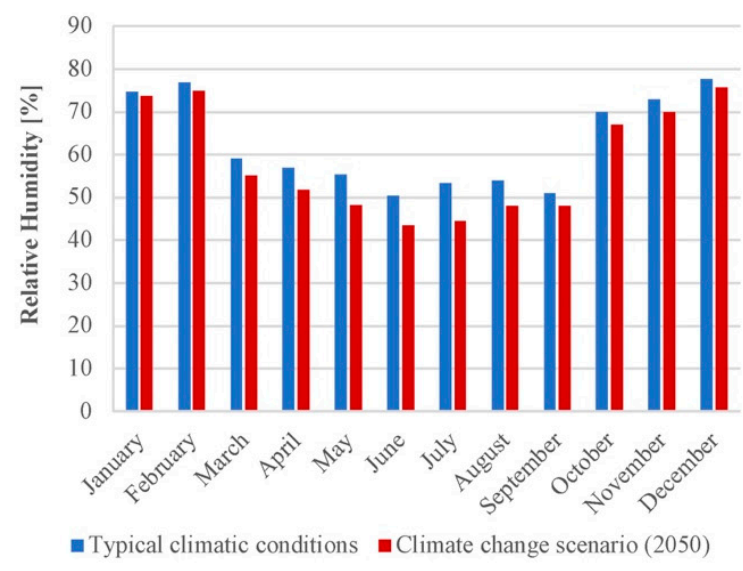

(c)

Figure 4. Monthly average of the hourly climate values for Seville, under typical climatic conditions and the 2050 climate scenario: (a) outdoor temperature; (b) global horizontal radiation; (c) relative humidity. 
The monthly average of the hourly values of global horizontal solar radiation will be increased to a lesser extent by the year 2050 (Figure 4b), and the air will become drier (Figure 4c).

\section{Results}

\subsection{Environmental Assessment of the Building Category}

For the evaluation of thermal comfort, the results obtained for the 750 case studies representing the building category (Table S1), both under typical climatic conditions and for the 2050 climate scenario (described in Section 3.2), were studied through histograms and the normal distribution established as the best fit. The percentage of discomfort hours was calculated for the winter $\left(\mathrm{DH}_{\mathrm{h}}\right)$ and summer $\left(\mathrm{DH}_{\mathrm{c}}\right)$ periods, as well as for the whole year $(\mathrm{DH})$, following the methods described in Section 2.1 and Section 2.2.

As can be observed in Figure 5 for the winter period (December-February), the influence of the 2050 climate scenario translates into a decrease in $\mathrm{DH}_{\mathrm{h}}$ for the building category studied, going from an average $\mathrm{DH}_{\mathrm{h}}$ value of $98.3 \%$ under typical climatic conditions, with a maximum of $100 \%$ and a minimum of $85 \%$, to one of $84.6 \%$, with a maximum of $100 \%$ and a minimum of $25 \%$. However, a major impact is observed during the summer period (June-August) (Figure 6), with a significant increase in the percentage of discomfort hours. $\mathrm{DH}_{\mathrm{c}}$ varies from an average value of $17.2 \%$ under typical climatic conditions, with a maximum of $74 \%$ and a minimum of $0 \%$, to one of $53.8 \%$ under the 2050 climate scenario, with a maximum of $97 \%$ and a minimum of $18 \%$.

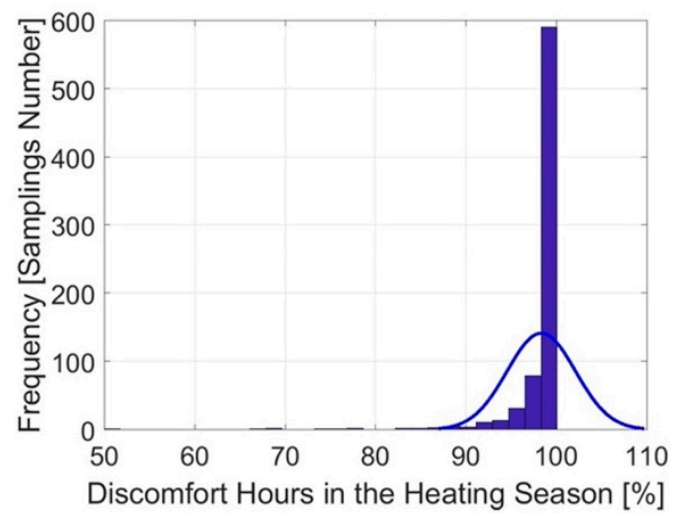

(a)

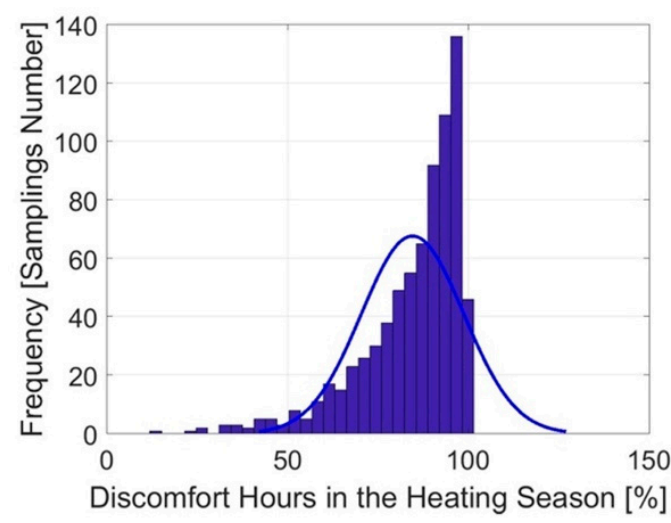

(b)

Figure 5. Distribution of $\mathrm{DH}_{\mathrm{h}}$ values in the building category. Winter period (December-February): (a) under typical climatic conditions; (b) for the 2050 climate scenario.

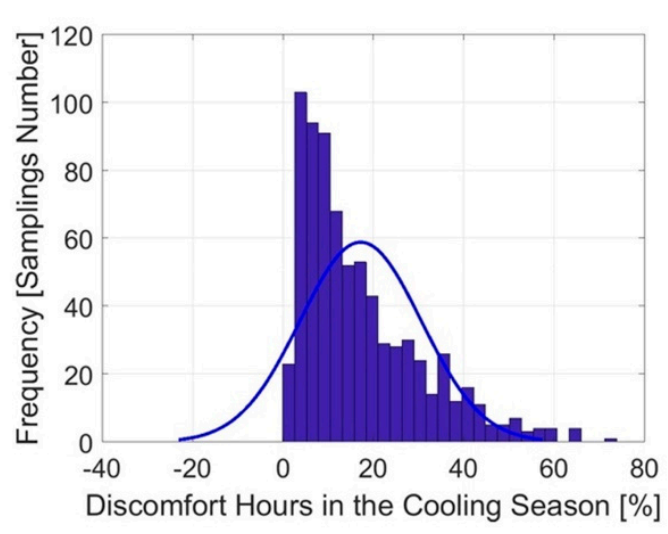

(a)

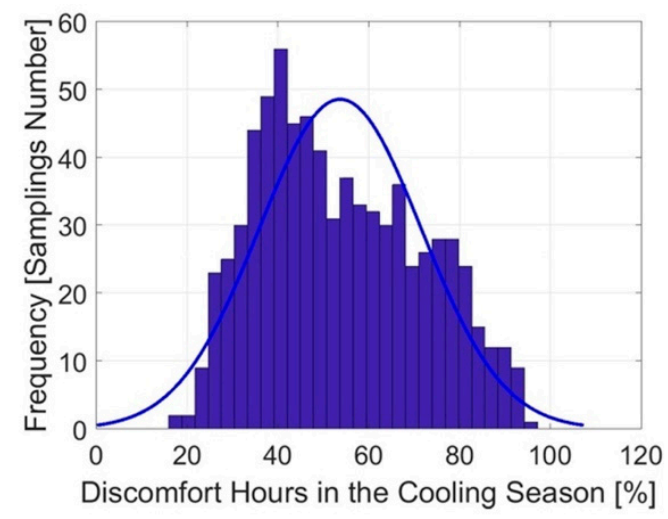

(b)

Figure 6. Distribution of $\mathrm{DH}_{\mathrm{c}}$ values in the building category. Summer period (June-August): (a) under typical climatic conditions; (b) for the 2050 climate scenario. 
Analysing the whole year (Figure 7), the influence of the 2050 climate scenario translates into an increase in the $\mathrm{DH}$, going from an average $\mathrm{DH}$ value of $36.1 \%$ under typical climatic conditions, with a maximum of $52 \%$ and a minimum of $20 \%$, to one of $40.5 \%$, with a maximum of $58 \%$ and a minimum of $15 \%$. In the annual study, the distribution of the results is very close to a normal one. Table 4 compiles the main results of the environmental assessment of the building category.

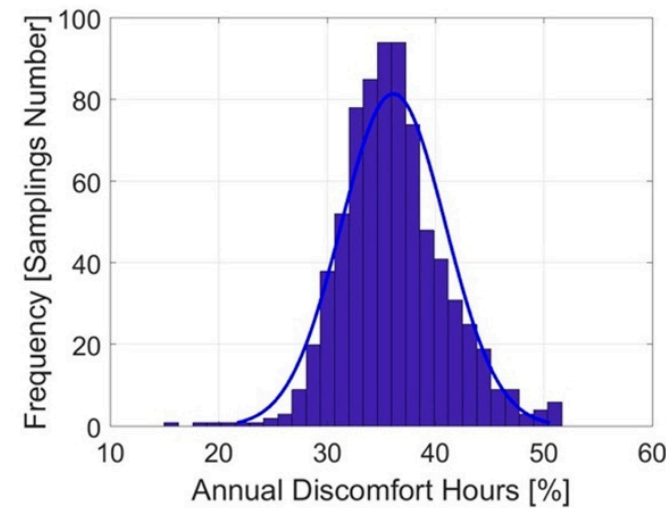

(a)

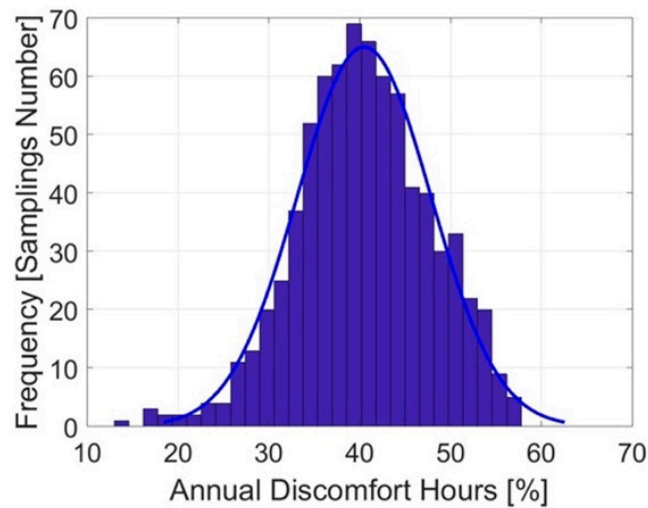

(b)

Figure 7. Distribution of DH values in the building category during a whole year: (a) under typical climatic conditions; (b) for the 2050 climate scenario.

Table 4. Main results of the environmental assessment of the building category.

\begin{tabular}{clcc}
\hline \multirow{2}{*}{ Title } & \multicolumn{1}{c}{ Title } & $\begin{array}{c}\text { Typical Climatic } \\
\text { Conditions }\end{array}$ & 2050 Climate Scenario \\
\hline \multirow{2}{*}{$\mathrm{DH}_{\mathrm{h}}[\%]$} & Average value & 98.3 & 84.6 \\
& Maximum value & 100 & 100 \\
& Minimum value & 85 & 25 \\
\hline \multirow{2}{*}{$\mathrm{DH}_{\mathrm{C}}[\%]$} & Average value & 17.2 & 53.8 \\
& Maximum value & 74 & 97 \\
& Minimum value & 0 & 18 \\
\hline \multirow{2}{*}{$\mathrm{DH}[\%]$} & Average value & 36.1 & 40.5 \\
& Maximum value & 52 & 58 \\
& Minimum value & 20 & 15 \\
\hline
\end{tabular}

The findings of the sensitivity analysis performed (see Section 2.1) (Figure 8) show that the parameters with the greatest influence on thermal comfort-i.e., the highest |SRRCs|-are those related to user behaviour (operational parameters). According to the literature, $|S R R C|$ values over 0.05 [38] or 0.1 [66] are considered relevant. With regards to the geometry, only 'floor height', 'form ratio', 'area of each floor' and orientation ('north axis') can be considered outstanding-with an $|S R R C|$ value over 0.20 . In this case, there are no important differences between the results under typical climatic conditions and the 2050 climate scenario. 

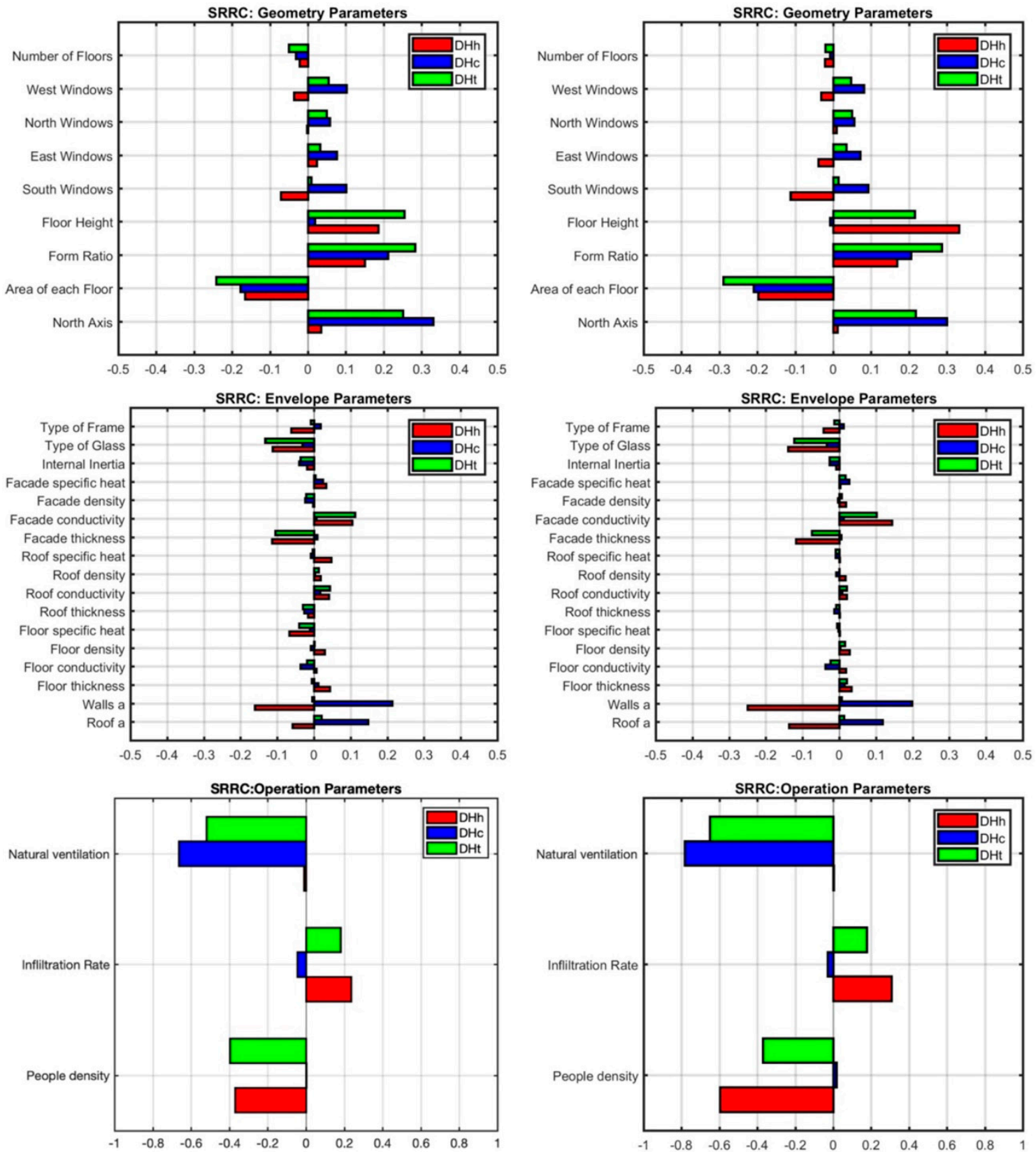

(a)

(b)

Figure 8. Standard rank regression coefficients (SRRCs) in relation to discomfort hours $\left(\mathrm{DH}_{\mathrm{h}}, \mathrm{DH}_{\mathrm{c}}\right.$ and $\mathrm{DH})$ for geometry, envelope and operation parameters: (a) under typical climatic conditions; (b) for the 2050 climate scenario.

Most envelope parameters have the lowest influence on $\mathrm{DH}$ values and only the absorptance of the wall's external layer ('wall a') achieves an $|S R R C|$ value of 0.20 for the summer period. The general trend of envelope parameters under the 2050 climate scenario reduces their level of influence. This is the result of an increase in the influence of operation parameters such as 'natural ventilation' and 'people density'. 'Natural ventilation' reaches an SRRC value of -0.80 for $\mathrm{DH}_{\mathrm{c}}$ and -0.65 for $\mathrm{DH}$ under the 2050 climate scenario. Higher 'natural ventilation' rates clearly cause a decrease in DH during most of the year, given the indoor overheating conditions expected. 


\subsection{Environmental Assessment of the 'Best' and the 'Worst' Case Study}

The cases with the lowest and the highest $\mathrm{DH}$ throughout the year were selected from the model representing the building category in order to analyse their environmental behaviour in further detail. The most significant parameters, |SRRCs| above 0.10, which define these two case studies are summarized in Table 5.

Table 5. Characterization of the 'best' and 'worst' case within the building category.

\begin{tabular}{|c|c|c|c|c|c|}
\hline \multicolumn{3}{|c|}{ Significant Parameters } & \multirow{2}{*}{$\begin{array}{c}\begin{array}{c}\text { 'Best } \\
\text { Case' }\end{array} \\
0^{\circ}\end{array}$} & \multirow{2}{*}{$\begin{array}{c}\text { ‘Worst } \\
\text { Case' }\end{array}$} & \multirow{2}{*}{$\begin{array}{c}\begin{array}{c}\text { Building } \\
\text { Category }\end{array} \\
0^{\circ}-180^{\circ}\end{array}$} \\
\hline Geometry & $\mathrm{P}_{1}$ & Orientation (North Axis) & & & \\
\hline & $\mathrm{P}_{2}$ & Area of each floor $\left[\mathrm{m}^{2}\right]$ & 273 & 114 & 90-300 \\
\hline & $\mathrm{P}_{3}$ & Form ratio ${ }^{1}$ & 2.4 & 2.1 & $1-5$ \\
\hline & $\mathrm{P}_{4}$ & Floor height $[\mathrm{m}]$ & 2.6 & 3.1 & $2.4-3.5$ \\
\hline \multirow[t]{7}{*}{ Envelope } & $P_{10}$ & Roof solar absorptance (a) & 0.3 & 0.4 & $0.1-0.9$ \\
\hline & $\mathrm{P}_{11}$ & Façade solar absorptance (a) & 0.6 & 0.5 & $0.1-0.9$ \\
\hline & $\mathrm{P}_{20}$ & Façade thickness $[\mathrm{m}]$ & 0.24 & 0.27 & $0.10-0.35$ \\
\hline & $\mathrm{P}_{21}$ & Façade thermal conductivity [W/m K] & 0.25 & 0.30 & $0.19-0.46$ \\
\hline & & Façade $\mathrm{U}$ value $\left[\mathrm{W} / \mathrm{m}^{2} \mathrm{~K}\right]$ & 1.04 & 1.11 & $0.75-4.35$ \\
\hline & $\mathrm{P}_{25}$ & Type of window glass & Double & Single & Single; Double \\
\hline & & Window $\mathrm{U}$ value $\left[\mathrm{W} / \mathrm{m}^{2} \mathrm{~K}\right]$ & 3.10 & 5.00 & $2.80-5.70$ \\
\hline \multirow[t]{3}{*}{ Operation } & $\mathrm{P}_{27}$ & People density [people $/ \mathrm{m}^{2}$ ] & 0.01 & 0.03 & $0.01-0.15$ \\
\hline & $\mathrm{P}_{28}$ & Infiltration rate $\left[\mathrm{h}^{-1}\right]$ & 0.6 & 0.5 & $0.3-1.0$ \\
\hline & $\mathrm{P}_{29}$ & Night-time natural ventilation rate $\left[\mathrm{h}^{-1}\right]$ & 6 & 0 & $0 ; 2 ; 4 ; 6$ \\
\hline
\end{tabular}

When analysing the hourly evolution of the temperature over a typical winter (Figure 9a) and summer day (Figure 9b), it is clear that the future climate scenario entails higher outdoor temperatures. There is an increase of up to $2{ }^{\circ} \mathrm{C}$ on the winter day evaluated. This increase is more noticeable in summer, up to $5.5^{\circ} \mathrm{C}$, reaching $47.5^{\circ} \mathrm{C}$ during the day. The minimum outdoor temperature for the summer day, during the night, is over $25^{\circ} \mathrm{C}$. This outdoor temperature increase logically translates into an increase of around $1.5^{\circ} \mathrm{C}$ on winter days and up to $5^{\circ} \mathrm{C}$ in summer in indoor temperatures.

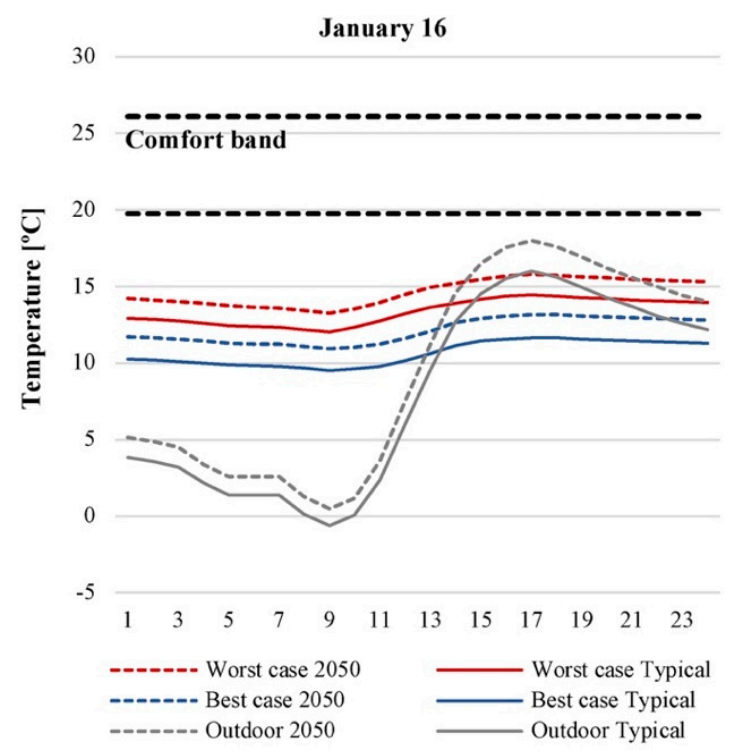

(a)

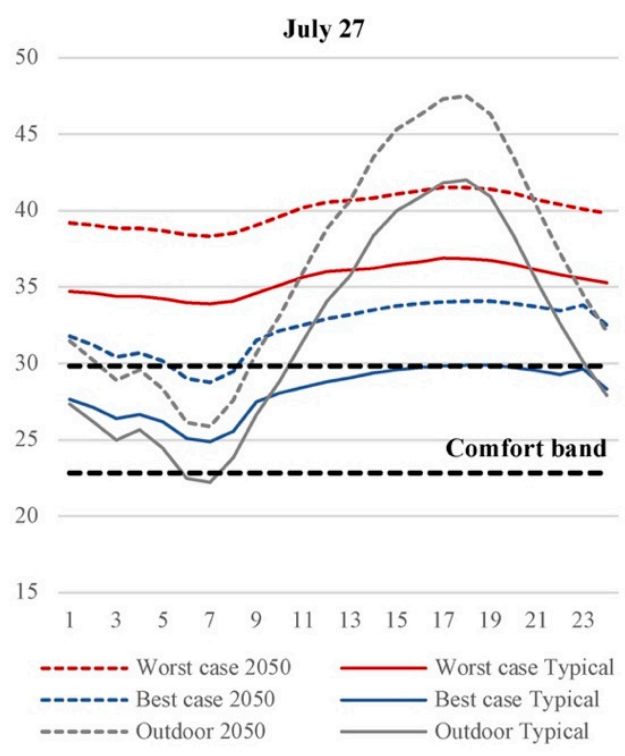

(b)

Figure 9. Hourly evolution of the indoor and outdoor air temperature, under typical climatic conditions and the 2050 climate scenario: (a) for a typical winter day; (b) for a typical summer day. 
The 'best' case study within the building category displays better behaviour than the 'worst' case during the summer spring and autumn periods, and consequently during the whole year. However, the opposite occurs during the winter period. This is mainly due to higher solar gain and airtightness in the 'worst' case. During the winter day under the climate change scenario, indoor temperatures for both case studies remain below the lower threshold of the comfort band, varying from $11^{\circ} \mathrm{C}$, minimum temperature for the 'best' case, to $16^{\circ} \mathrm{C}$, maximum temperature for the 'worst' case. However, the environmental behaviour of the building category is still worse in summer under the climate change scenario, since most of the time the 'best' case is above the upper threshold of the comfort band, reaching an indoor temperature of $34^{\circ} \mathrm{C}$, while the 'worst' case clearly suffers from indoor overheating, reaching $42{ }^{\circ} \mathrm{C}$ during the day and remaining above $38^{\circ} \mathrm{C}$ during the night.

\subsection{Energy Assessment of the 'Best' and the 'Worst' Case Study}

Current Spanish construction regulations (CTE DB-HE1 [9]) set a restriction on the heating energy demand of $15 \mathrm{kWh} / \mathrm{m}^{2}$ per year in winter climate zone B and $20 \mathrm{kWh} / \mathrm{m}^{2}$ per year for cooling in summer climate zone 4 . Although these limitations of heating and cooling demands only apply to new buildings under current climatic conditions, these values can be used as a reference in order to establish a scale of low or high demands.

When estimating the annual energy demand for the 'best' and 'worst' case representing the building category (Figure 10), under the climate change scenario, it can be observed that both cases have a medium heating demand, slightly over the CTE limit, but a high cooling demand, between 1.8 ('best' case) and 4.6 times the CTE regulation ('worst' case).

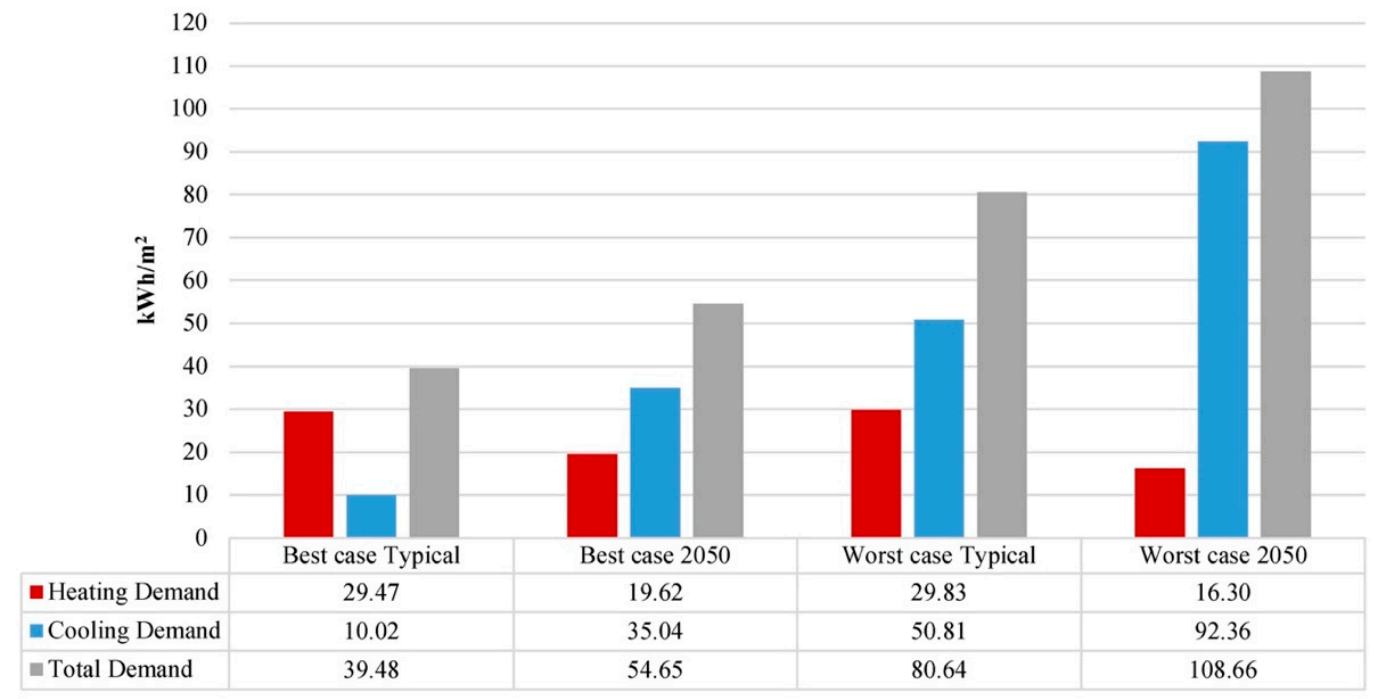

Figure 10. Energy demand under typical climatic conditions and the 2050 climate scenario.

A clear impact is detected on energy demand when comparing the results under typical climatic conditions and under the climate change scenario. While heating demand will be slightly reduced, cooling demand could even triple for the year 2050. The annual demand estimated for the 2050 scenario is over $50 \mathrm{kWh} / \mathrm{m}^{2}$ in the 'best' case and almost $110 \mathrm{kWh} / \mathrm{m}^{2}$ in the 'worst' case.

\section{Discussion}

The results obtained in this work and detailed in the previous sections predict a generalized worsening of indoor thermal comfort conditions for the climate change scenario. Although these results are in line with the conclusions from similar studies, they are even more worrying given the energy vulnerability of the building category evaluated and severe summer climatic conditions in the location selected. 
Similar research carried out in the Mediterranean climate, such as that by Kapsomenakis et al. [7] on an office building in Greece or that by Pierangioli et al. [67] on an apartment building in Italy, established an increase in cooling demand for 2050 of 25 and almost $10 \mathrm{kWh} / \mathrm{m}^{2}$ respectively. In the Greek case study, the increase is between 15 and $29 \%$, while in the Italian case study, it is around 30\%. Cellura et al. [68] evaluated the impact of climate change in office buildings, designed following current thermal regulations in different cities of southern Europe. In Valencia (eastern Spain), a rise in cooling demand of up to $30 \mathrm{kWh} / \mathrm{m}^{2}, 220 \%$ in relative terms, is estimated for the year 2035. Nevertheless, as this study focuses on a case study with very low thermal performance, that increase is estimated to range from 25 to more than $41 \mathrm{kWh} / \mathrm{m}^{2}$. This translates into several relative increments of current cooling demand, up to $250 \%$. The energy assessment of detached houses designed according to current Spanish regulations by Pérez-Andreu et al. [69] in eastern Spain and by Suárez et al. [8] in southern Spain concluded that the cooling demand will have more than doubled in 2050, with a predicted increase in the average monthly outdoor temperature of between 3 and $4{ }^{\circ} \mathrm{C}$. In the case study from eastern Spain, cooling demand will increase from $15 \mathrm{kWh} / \mathrm{m}^{2}$ to $40 \mathrm{kWh} / \mathrm{m}^{2}$, while in the case study in southern Spain it will go from 20 to $40 \mathrm{kWh} / \mathrm{m}^{2}$. In the building category under here, it is estimated that this demand will even triple, rising from 10 to $35 \mathrm{kWh} / \mathrm{m}^{2}$ for the 'best' case, with a predicted increase in average monthly outdoor temperature of over $4{ }^{\circ} \mathrm{C}$.

There is a lack of research quantifying the impact of climate change in the Mediterranean climate in terms of thermal comfort. In this study, it is estimated that the percentage of discomfort hours during the summer period in the building category studied will increase by an average of $36.6 \%$ in 2050, while Barbosa et al. [70], analysing a similar building in Lisbon, concluded that this increase will be under $17 \%$. It should be taken into account that Barbosa's work applied the ISO-EN-15251 adaptive thermal comfort standard [53], which is less restrictive than that used in this study [55]. Both studies concluded that operational parameters have the highest influence on thermal comfort.

In this work, the impact of climate change has been quantified both in terms of thermal comfort and energy demand. In the residential stock evaluated, the average percentage of discomfort hours will go from 17 to $54 \%$ in 2050 , i.e., it will triple. The estimated cooling demand for the 'best' case will increase from 10 to $35 \mathrm{kWh} / \mathrm{m}^{2}$ in 2050, more than triple, while for the 'worst' case it will go from 51 to $92 \mathrm{kWh} / \mathrm{m}^{2}$, almost double. In this case study, the results obtained in terms of comfort are much more representative of the real behaviour of the dwellings, given that there is almost no use of HVAC systems due to socio-economic reasons. However, the evaluation of the global warming impact in terms of energy demand showcases the needs of this case study to ensure full thermal comfort. Regarding the assessment of climate change impact, most studies focus on the quantification of heating and cooling demand $[7,67,69]$. The main contribution of the proposed methodology is the ability to quantify the impact of climate change, in terms of adaptive thermal comfort, in an entire building category representing more than $40 \%$ of post-war housing stock from southern Spain, rather than focusing the study on a specific building as is frequently found in the available literature [70-72]. Despite some references with similar aims in northern Europe [73], published research on this topic is very limited in the south, where climate change will be most noticeable.

Mostly as a result of the inclusion of the perspective of a future climate scenario, this becomes a very useful tool for characterizing the environmental performance of the housing stock before proposing retrofitting plans which are urgently required to avoid energy poverty within this building category. It makes no sense to retrofit considering current building performance without looking to the future, given that the intervention would immediately become obsolete.

\section{Strengths and Limitations}

The reliability of the results obtained in this work is supported by the careful simulation process carried out using the EnergyPlus simulation tool, which is widely validated by the scientific community $[35,74,75]$. This process takes a model calibrated thanks to in-situ measurements as a starting point [37], resulting in a yearly value of NMBE under 3\% and a CV(RMSE) value of 7\%, 
far below the limits established in ASHRAE Guideline 14-2014 [76]. In addition, the 'morphing' method applied for projecting the weather file for the year 2050, described in Section 2.3. [57], is one of the most widely used and best regarded by the scientific community $[59,77]$.

However, the method applied also has some limitations, which are discussed in this section. The building stock model developed in this work demonstrates the great potential of broadening the sample size, controlling modelling and computation effort [38]. However, this requires the simplification or generalization of some modelling parameters which greatly affect the thermal and energy behaviour of buildings. This is the case of user profiles, which are specific to each case study, with different occupation schedules and preferences for HVAC use [22]. The ranges of variability proposed in this work for the operational parameters are based on user profiles defined through in-situ measurements in a limited sample [50,51], but these should be improved in the future through a statistical study on a larger sample representing all types of families and socioeconomic conditions. In addition, given that operational parameters were found to be the most relevant for thermal comfort in this case study, new variables such as the use of solar shading devices or light and equipment loads should be considered.

This paper focuses on the energy and environmental characterization of a particular building category, limited to post-war linear geometric typology in Seville. However, it should be feasible to complete this characterization by extending the methods applied in this work to other building categories, including all significative typologies, such as $\mathrm{H}$-shape and high-rise [61], and climate zones of the Mediterranean area. Future work will aim to address this.

Another possibility for future research is the incorporation of this prediction model as a plugin into Building Information Modelling (BIM) tools. It should read the building properties, replacing the characteristic parameters with the corresponding values in order to easily obtain the IDF file for the simulation in EnergyPlus, which will in turn provide the thermal comfort assessment.

The characterization of the energy and environmental behaviour of the housing stock under the future climate change scenario is a great starting point for proposing retrofitting measures. However, the building stock model developed in this work should be improved by including the evaluation of the energy performance of proven retrofitting measures [78]. For future research, the authors are currently working on the optimized evaluation of different passive retrofitting strategies recognized by the scientific community as the most effective for the Mediterranean climate $[8,15,36]$. These include night-time ventilation, window shading devices and the adoption of reflective coatings for the building shell, in order to improve thermal comfort conditions under a climate change scenario.

\section{Conclusions}

This study evaluates the influence of global warming on the environmental performance of an entire building category, by comparing the results obtained under typical climatic conditions and under an A2 climate change scenario for 2050. It was evaluated in terms of comfort, checking the increase of the percentage of hours outside the comfort band in 2050; that of outdoor and indoor air temperatures, quantified in degrees; and that of energy demand, quantifying the annual cooling requirement $\left(\mathrm{kWh} / \mathrm{m}^{2}\right)$. This contributes to filling the gap in research assessing the effects of global warming on adaptive thermal comfort under the severe summer climate conditions of the Mediterranean arch. Furthermore, there is an added value provided by the development of simulation models representing an important part of the residential stock, instead of a particular case study.

An increase in average monthly outdoor temperatures of about $1.5^{\circ} \mathrm{C}$ in winter and $4.0^{\circ} \mathrm{C}$ in summer is expected by the year 2050 in Seville. This will logically have a major impact on thermal comfort, indoor temperatures and energy demand.

Based on the characterization of the thermal comfort in post-war linear-type multi-family social housing in southern Spain, it can be determined that the increase in outdoor temperatures predicted for 2050 will reduce the percentage of discomfort hours in winter but give rise to a major increase in summer. There will be an average increase of $36.6 \%$ in discomfort hours in summer for the building category. 
The results from the sensitivity analysis demonstrate the major influence of user behaviour on thermal comfort in this case study, which will increase with climate change. This should encourage energy policies requiring the characterization of user profiles prior to the proposal of retrofitting measures and their evaluation under climate conditions for 2050. Due to global warming, passive strategies such as natural ventilation will be essential in reducing indoor overheating conditions expected in the future.

The environmental evaluation of the cases with the lowest and highest percentage of discomfort hours throughout the year on a typical winter and summer day gives rise to a large increase in outdoor temperatures in a climate change scenario, up to $2{ }^{\circ} \mathrm{C}$ in winter and $5.5^{\circ} \mathrm{C}$ in summer, reaching temperatures of $47.5^{\circ} \mathrm{C}$. Therefore, a large increase in indoor temperatures is also predicted for the summer, up to $5{ }^{\circ} \mathrm{C}$, with a maximum daytime value of $42{ }^{\circ} \mathrm{C}$ as the 'worst' case, and a minimum value of $29^{\circ} \mathrm{C}$ during the night as the 'best' case. These values are clearly far from adaptive thermal comfort conditions. The estimated cooling demand for these case studies will also notably increase under the climate change scenario, reaching up to three times the results obtained for typical climatic conditions.

It is essential to take the severe repercussions of the climate change scenario in southern Spain into account when planning future energy retrofit policies badly needed for this housing stock. The next steps in this research will aim to propose retrofitting measures based on the results of this characterization for a 2050 climate projection, as well as on the sensitivity analysis, in combination with an economic assessment.

Supplementary Materials: The following are available online at http://www.mdpi.com/1996-1073/12/12/2238/s1, Table S1: Description of case studies.

Author Contributions: Conceptualization, R.E., R.S. and J.J.S.; Investigation, R.E. and R.S.; Methodology, all authors; Writing—original draft, all authors.

Funding: This research was funded by the Spanish government through the research and development project "Parametric optimization of double-skin façades in the Mediterranean climate to improve energy efficiency under climate change scenarios" (ref BIA2017-86383-R).

Conflicts of Interest: The funders had no role in the design of the study; in the collection, analyses, or interpretation of data; in the writing of the manuscript, or in the decision to publish the results

\section{Nomenclature}

$\begin{array}{ll}\mathrm{DH} & \text { Annual percentage of discomfort hours } \\ \mathrm{DH}_{\mathrm{h}} & \text { Percentage of discomfort hours (heating period) } \\ \mathrm{DH}_{\mathrm{c}} & \text { Percentage of discomfort hours (cooling period) } \\ \mathrm{HVAC} & \text { Heating, ventilating and air conditioning } \\ \mathrm{IPCC} & \text { Intergovernmental Panel on Climate Change } \\ \mathrm{N} & \text { Sample size (number of cases) } \\ \text { PMV } & \text { Predicted mean vote } \\ \text { PPD } & \text { Predicted percentage of dissatisfied } \\ \text { SA } & \text { Sensitivity analysis } \\ \text { SLABE } & \text { Simulation-based large-scale uncertainty/sensitivity analysis of building energy performance } \\ \text { SRRC } & \text { Standardized rank regression coefficient } \\ \text { Tco } & \text { Optimum comfort temperature }\left[{ }^{\circ} \mathrm{C}\right] \\ \mathrm{U} & \text { Thermal transmittance }\left[\mathrm{W} / \mathrm{m}^{2} \mathrm{~K}\right] \\ \mathrm{UA} & \text { Uncertainty analysis }\end{array}$

\section{References}

1. Eurostat. Final Energy Consumption by Sector. 2015. Available online: http://ec.europa.eu/eurostat/statisticsexplained/index.php/Consumption_of_energy\#Consumption (accessed on 19 March 2019).

2. Intergovernmental Panel on Climate Change (IPCC). Available online: https://www.ipcc.ch/ (accessed on 19 March 2019). 
3. IPCC. Special Report on Emissions Scenarios (SRES); Nakicenovic, N., Swart, R., Eds.; Cambridge University Press: Cambridge, UK, 2000; Available online: https://www.ipcc.ch/report/emissions-scenarios/ (accessed on 19 March 2019).

4. Andrić, I.; Koc, M.; Al-Ghamdi, S.G. A review of climate change implications for built environment: Impacts, mitigation measures and associated challenges in developed and developing countries. J. Clean. Prod. 2019, 211, 83-102. [CrossRef]

5. Li, D.H.W.; Yang, L.; Lam, J.C. Impact of climate change on energy use in the built environment in different climate zones-A review. Energy 2012, 42, 103-112. [CrossRef]

6. Santamouris, M. Cooling the buildings-Past, present and future. Energy Build. 2016, 128, 617-638. [CrossRef]

7. Kapsomenakis, J.; Kolokotsa, D.; Nikolaou, T.; Santamouris, M.; Zerefos, F.C. Forty years increase of the air ambient temperature in Greece: The impact on buildings. Energy Convers. Manag. 2013, 74, $353-365$. [CrossRef]

8. Suárez, R.; Escandón, R.; López-Pérez, R.; León-Rodríguez, Á.L.; Klein, T.; Silvester, S. Impact of climate change: Environmental assessment of passive solutions in a single-family home in Southern Spain. Sustainability 2018, 10, 2914. [CrossRef]

9. Ministerio de Vivienda. Código Técnico de la Edificación (CTE) Documento Básico de Ahorro de Energía (DB-HE). 2013. Available online: http://www.codigotecnico.org/images/stories/pdf/ahorroEnergia/DBHE.pdf (accessed on 6 March 2019).

10. Santamouris, M.; Kolokotsa, D. On the impact of urban overheating and extreme climatic conditions on housing, energy, comfort and environmental quality of vulnerable population in Europe. Energy Build. 2015, 98, 125-133. [CrossRef]

11. Coley, D.; Kershaw, T. Changes in internal temperatures within the built environment as a response to a changing climate. Build. Environ. 2010, 45, 89-93. [CrossRef]

12. The European Platform against Poverty and Social Exclusion: A European Framework for Social and Territorial cohesion. In Communication from the Commission to the European Parliament, the Council, the European Economic and Social Committee and the Committee of the Regions; European Commission: Brussels, Belgium, 2010.

13. Sanchez-Guevara, C.; Núñez-Peiró, M.; Taylor, J.; Mavrogianni, A.; Neila, J. Assessing population vulnerability towards summer energy poverty: Case studies of Madrid and London. Energy Build. 2019, 190, 132-143. [CrossRef]

14. Sepasgozar, S.M.E.; Blair, J. Measuring non-road diesel emissions in the construction industry: A synopsis of the literature. Int. J. Constr. Manag. 2019. [CrossRef]

15. Ascione, F.; Bianco, N.; De Masi, R.F.; Mauro, G.M.; Vanoli, G.P. Resilience of robust cost-optimal energy retrofit of buildings to global warming: A multi-stage, multi-objective approach. Energy Build. 2017, 153, 150-167. [CrossRef]

16. Spanish Statistics National Institute. Censos de Población y Viviendas. 2011. Available online: http: //www.ine.es/censos2011/tablas/Inicio.do (accessed on 19 March 2019).

17. Di Pilla, L.; Desogus, G.; Mura, S.; Ricciu, R.; Di Francesco, M. Optimizing the distribution of Italian building energy retrofit incentives with Linear Programming. Energy Build. 2016, 112, 21-27. [CrossRef]

18. Calama-González, C.M.; Suárez, R.; León-Rodríguez, Á.L.; Domínguez-Amarillo, S. Evaluation of thermal comfort conditions in retrofitted facades using test cells and considering overheating scenarios in a Mediterranean climate. Energies 2018, 11, 788. [CrossRef]

19. Ascione, F.; Rossi, F.; Vanoli, G.P. Energy retrofit of historical buildings: Theoretical and experimental investigations for the modelling of reliable performance scenarios. Energy Build. 2011, 43, 1925-1936. [CrossRef]

20. Escandón, R.; Silvester, S.; Konstantinou, T. Evaluating the environmental adaptability of a nearly zero energy retrofitting strategy designed for Dutch housing stock to a Mediterranean climate. Energy Build. 2018, 169, 366-378. [CrossRef]

21. Sunikka-Blank, M.; Galvin, R. Introducing the prebound effect: The gap between performance and actual energy consumption. Build. Res. Inf. 2012, 40, 260-273. [CrossRef]

22. Guerra-Santín, O.; Itard, L. Occupants' behaviour: Determinants and effects on residential heating consumption. Build. Res. Inf. 2010, 38, 318-338. [CrossRef] 
23. Kavgic, M.; Mavrogianni, A.; Mumovic, D.; Summerfield, A.; Stevanovic, Z.; Djurovic-Petrovic, M. A review of bottom-up building stock models for energy consumption in the residential sector. Build. Environ. 2010, 45, 1683-1697. [CrossRef]

24. Kragh, J.; Wittchen, K.-B. Development of two Danish building typologies for residential buildings. Energy Build. 2014, 68, 79-86. [CrossRef]

25. Streicher, K.N.; Padey, P.; Parra, D.; Bürer, M.C.; Patel, M.K. Assessment of the current thermal performance level of the Swiss residential building stock: Statistical analysis of energy performance certificates. Energy Build. 2018, 178, 360-378. [CrossRef]

26. Dascalaki, E.G.; Droutsa, K.; Gaglia, A.G.; Kontoyiannidis, S.; Balaras, C.A. Data collection and analysis of the building stock and its energy performance-An example for Hellenic buildings. Energy Build. 2010, 42, 1231-1237. [CrossRef]

27. Theodoridou, I.; Papadopoulos, A.M.; Hegger, M. Statistical analysis of the Greek residential building stock. Energy Build. 2011, 43, 2422-2428. [CrossRef]

28. Swan, L.G.; Ugursal, V.I. Modeling of end-use energy consumption in the residential sector: A review of modeling techniques. Renew. Sustain. Energy Rev. 2009, 13, 1819-1835. [CrossRef]

29. US Department of Energy. Energy Efficiency and Renewable Energy Office, Building Technology Program, EnergyPlus 8.0.0. Available online: https://energyplus.net/ (accessed on 6 March 2019).

30. ESP-r. Available online: http://www.esru.strath.ac.uk/Programs/ESP-r.htm (accessed on 6 March 2019).

31. TRNSYS. Transient System Simulation Program; University of Wisconsin: Madison, WI, USA, 2000.

32. Wang, D.; Landolt, J.; Mavromatidis, G.; Orehounig, C.; Carmeliet, J. CESAR: A bottom-up building stock modelling tool for Switzerland to address sustainable energy transformation strategies. Energy Build. 2018, 169, 9-26. [CrossRef]

33. Penna, P.; Prada, A.; Cappelletti, F.; Gasparella, A. Multi-objectives optimization of energy saving measures in existing buildings. Energy Build. 2015, 95, 57-69. [CrossRef]

34. Li, Y.F.; Ng, S.H.; Xie, M.; Goh, T.N. A systematic comparison of metamodeling techniques for simulation optimization in decision support systems. Appl. Soft. Comput. 2010, 10, 1257-1273. [CrossRef]

35. Melo, A.P.; Cóstola, D.; Lamberts, R.; Hensen, J.L. Development of surrogate models using artificial neural network for building shell energy labeling. Energy Policy 2014, 69, 457-466. [CrossRef]

36. Santamouris, M. On the energy impact of urban heat island and global warming on buildings. Energy Build. 2014, 82, 100-113. [CrossRef]

37. Escandón, R.; Ascione, F.; Bianco, N.; Mauro, G.M.; Suárez, R.; Sendra, J.J. Thermal comfort prediction in a building category: Artificial neural network generation from calibrated models for a social housing stock in Southern Europe. App. Thermal Eng. 2019, 150, 492-505. [CrossRef]

38. Mauro, G.M.; Hamdy, M.; Vanoli, G.P.; Bianco, N.; Hensen, J.L.M. A new methodology for investigating the cost-optimality of energy retrofitting a building category. Energy Build. 2015, 107, 456-478. [CrossRef]

39. Helton, J.C.; Johnson, J.D.; Sallaberry, C.; Storlie, C.B. Survey of sampling-based methods for uncertainty and sensitivity analysis. Reliab. Eng. Syst. Saf. 2006, 91, 1175-1209. [CrossRef]

40. Hopfe, C.J.; Hensen, J.L. Uncertainty analysis in building performance simulation for design support. Energy Build. 2011, 43, 2798-2805. [CrossRef]

41. Conraud, J. A Methodology for the Optimization of Building Energy, Thermal, and Visual Performance. Master Thesis, Concordia University, Montreal, QC, Canada, 2008.

42. MATLAB ${ }^{\circledR}-M A T r i x L A B o r a t o r y ; 7.10 .0 . ;$ MathWorks: Natick, MA, USA, 2010.

43. Nguyen, A.T.; Reiter, S.; Rigo, P. A review on simulation-based optimization methods applied to building performance analysis. Appl. Energy 2014, 113, 1043-1058. [CrossRef]

44. Tian, W. A review of sensitivity analysis methods in building energy analysis. Renew. Sustain. Energy Rev. 2013, 20, 411-419. [CrossRef]

45. Fanger, P.P. Thermal Comfort: Analysis and Applications on Environmental Technology; Danish Technical Press: Copenhagen, Denmark, 1970.

46. ISO. Standard ISO 7730:2005, Moderate Thermal Environments Determination of the PMV and PPD Indices and Specification of the Conditions for Thermal Comfort; International Organization for Standardization (ISO): Geneva, Switzerland, 2005.

47. Humphreys, M.A. Field studies of thermal comfort compared and applied. Build. Serv. Eng. 1976, 44, 5-27. 
48. Moujalled, B.; Cantin, R.; Guarracino, G. Comparison of thermal comfort algorithms in naturally ventilated office buildings. Energy Build. 2008, 40, 2215-2223. [CrossRef]

49. Djongyang, N.; Tchinda, R.; Njomo, D. Thermal comfort: A review paper. Renew. Sustain. Energy Rev. 2010, 14, 2626-2640. [CrossRef]

50. Escandón, R.; Suárez, R.; Sendra, J.J. On the assessment of the energy performance and environmental behaviour of social housing stock for the adjustment between simulated and measured data: The case of mild winters in the Mediterranean climate of Southern Europe. Energy Build. 2017, 152, 418-433. [CrossRef]

51. Escandón, R.; Suárez, R.; Sendra, J.J. Field assessment of thermal comfort conditions and energy performance of social housing: The case of hot summers in the Mediterranean climate. Energy Policy 2019, 128, 377-392. [CrossRef]

52. ASHRAE. Thermal Environmental Conditions for Human Occupancy. In Standard 55-2010; American Society of Heating, Refrigerating and Air Conditioning Engineers: Atlanta, GA, USA, 2010.

53. European Committee for Standardization (CEN). Indoor environmental input parameters for design and assessment of energy performance of buildings-addressing indoor air quality, thermal environment, lighting and acoustics. In Standard EN 15251; CEN: Brussels, Belgium, 2007.

54. European Committee for Standardization (CEN). CEN/TC 156. prEN 16798-1:2015. Energy Performance of Buildings-Part 1: Indoor Environmental Input Parameters for Design and Assessment of Energy Performance of Buildings Addressing Indoor Air Quality, Thermal Environment, Lighting and Acoustics-Module M1-6; CEN: Brussels, Belgium, 2015.

55. Barbadilla-Martín, E.; Salmerón, J.M.; Guadix, J.; Aparicio-Ruiz, P.; Brotas, L. Field study on adaptive thermal comfort in mixed mode office buildings in southwestern area of Spain. Build. Environ. 2017, 123, 163-175. [CrossRef]

56. University of Southampton. Climate Change World Weather File Generator for World-Wide Weather Data-CCWorldWeatherGen. Available online: http://www.energy.soton.ac.uk/ccworldweathergen/ (accessed on 16 February 2019).

57. Belcher, S.E.; Hacker, J.N.; Powell, D.S. Constructing design weather data for future climates. Build. Serv. Eng. Res. Technol. 2005, 26, 49-61. [CrossRef]

58. EnergyPlus Weather Database. Available online: https://energyplus.net/weather (accessed on 16 February 2019).

59. Jentsch, M.F.; James, P.A.B.; Bourikas, L.; Bahaj, A.S. Transforming existing weather data for worldwide locations to enable energy and building performance simulation under future climates. Renew. Energy 2011, 55, 514-524. [CrossRef]

60. IPCC Data distribution Centre. Available online: http://www.ipcc-data.org/ (accessed on 16 February 2019).

61. Domínguez, S.; Sendra, J.J.; Fernández-Agüera, J.; Escandón, R. La Construcción de la Vivienda Social en Sevilla y su Catalogación: 1939-1975; Editorial de la Universidad de Sevilla: Sevilla, Spain, 2017.

62. R\&D\&i Project REFAVIV. Available online: http://proyectorefaviv.ietcc.csic.es/ (accessed on 6 March 2019).

63. Sech-Spahousec Project-Analysis of the Energy Consumption in the Spanish Households. Available online: https://www.idae.es/uploads/documentos/documentos_Informe_SPAHOUSEC_ACC_f68291a3.pdf(accessed on 6 March 2019).

64. AEMET. Agencia Estatal de Meteorología de España. Available online: http://www.aemet.es/es/ serviciosclimaticos/datosclimatologicos/valoresclimatologicos?l=5783\&k=and (accessed on 6 March 2019).

65. Fernández-Agüera, J.; Domínguez-Amarillo, S.; Sendra, J.J.; Suárez, R.; Oteiza, I. Social housing airtightness in Southern Europe. Energy Build. 2019, 183, 377-391. [CrossRef]

66. Yildiz, Y.; Korkmaz, K.; Göksal Özbalta, T.; Durmus Arsan, Z. An approach for developing sensitive design parameter guidelines to reduce the energy requirements of low-rise apartment buildings. Appl. Energy 2012, 93, 337-347. [CrossRef]

67. Pierangioli, L.; Cellai, G.; Ferrise, R.; Trombi, G.; Bindi, M. Effectiveness of passive measures against climate change: Case studies in Central Italy. Build. Simul. 2017, 10, 459-479. [CrossRef]

68. Cellura, M.; Guarino, F.; Longo, S.; Tumminia, G. Climate change and the building sector: Modelling and energy implications to an office building in southern Europe. Energy Sustain. Develop. 2018, 45, 46-65. [CrossRef] 
69. Pérez-Andreu, V.; Aparicio-Fernández, C.; Martínez-Ibernón, C.; Vivancos, J.L. Impact of climate change on heating and cooling energy demand in a residential building in a Mediterranean climate. Energy 2018, 165, 63-74. [CrossRef]

70. Barbosa, R.; Vicente, R.; Santos, R. Climate change and thermal comfort in Southern Europe housing: A case study from Lisbon. Build. Environ. 2015, 92, 440-451. [CrossRef]

71. Dino, I.G.; Akgül, C.M. Impact of climate change on the existing residential building stock in Turkey: An analysis on energy use, greenhouse gas emissions and occupant comfort. Renew. Energy 2019, 141, 828-846. [CrossRef]

72. Ozarisoy, B.; Elsharkawy, H. Assessing overheating risk and thermal comfort in state-of-the-art prototype houses that combat exacerbated climate change in UK. Energy Build. 2019, 187, 201-217. [CrossRef]

73. Hamdy, M.; Carlucci, S.; Hoes, P.J.; Hensen, J.L.M. The impact of climate change on the overheating risk in dwellings-A Dutch case study. Build. Environ. 2017, 122, 307-323. [CrossRef]

74. Pezeshki, Z.; Soleimani, A.; Darabi, A. Application of BEM and using BIM database for BEM: A review. J. Build. Eng. 2019, 23, 1-17. [CrossRef]

75. Crawley, D.B.; Lawrie, L.K.; Winkelmann, F.C.; Buhl, W.F.; Huang, Y.J.; Pedersen, C.O.; Strand, R.K.; Liesen, R.J.; Fisher, D.E.; Witte, M.J.; et al. EnergyPlus: Creating a new-generation building energy simulation program. Energy Build. 2001, 33, 319-331. [CrossRef]

76. ASHRAE. ASHRAE Guideline 14-2014: Measurement of Energy, Demand and Water Savings; American Society of Heating, Refrigerating and Air Conditioning Engineers: Atlanta, GA, USA, 2014.

77. CIBSE. Use of Climate Change Scenarios for Building Simulation: The CIBSE Future Weather Years-CIBSE TM48; The Chartered Institution of Building Services Engineers: London, UK, 2009.

78. Ascione, F. Energy conservation and renewable technologies for buildings to face the impact of the climate change and minimize the use of cooling. Sol. Energy 2017, 154, 34-100. [CrossRef]

(C) 2019 by the authors. Licensee MDPI, Basel, Switzerland. This article is an open access article distributed under the terms and conditions of the Creative Commons Attribution (CC BY) license (http://creativecommons.org/licenses/by/4.0/). 